\title{
Prey switching of Dall's porpoise Phocoenoides dalli with population decline of Japanese pilchard Sardinops melanostictus around Hokkaido, Japan
}

\author{
Hiroshi Ohizumi ${ }^{1, *}$, Toshiaki Kuramochi ${ }^{2}$, Masao Amano ${ }^{1}$, Nobuyuki Miyazaki $^{1}$ \\ ${ }^{1}$ Otsuchi Marine Research Center, Ocean Research Institute, The University of Tokyo, Akahama, Otsuchi, \\ Iwate 028-1102, Japan \\ ${ }^{2}$ Department of Zoology, National Science Museum, Hyakunincho, Shinjuku, Tokyo 160-0073, Japan
}

\begin{abstract}
The stomach contents of 150 Dall's porpoises collected during 6 surveys in the Sea of Japan and Sea of Okhotsk around Hokkaido in 1988 to 1996 were examined. A total of 49 prey types, including 29 species, were identified. Epipelagic prey items were found in samples collected during midday, and mesopelagic and some benthopelagic prey species were found in samples collected in the morning. Although the size range of prey was great, most prey were small. The dominant prey species switched in both seas from the late 1980s to the early 1990s as the Sardinops melanostictus (Japanese pilchard) populations in the both seas declined. In the Sea of Japan, the diet of Dall's porpoises switched to Theragra chalcogramma (walleye pollock), and in the Sea of Okhotsk, their diet switched to Engraulis japonicus (Japanese anchovy) and Berryteuthis magister (magistrate armhook squid). The utilization of new prey species did not always coincide with the fluctuation in catch statistics for the prey in local fisheries. Dall's porpoises fed on many benthopelagic prey species when epipelagic prey species were not available, suggesting that epipelagic prey species are the preferred prey. The vertical distribution of prey presumably affects prey selection.
\end{abstract}

KEY WORDS: Phocoenoides dalli Sea of Japan - Sea of Okhotsk · Prey switching · population decline - Sardinops melanostictus · Prey distribution

\section{INTRODUCTION}

Dolphins and porpoises in coastal waters often feed on small shoaling fishes, such as sardines. Sometimes, the abundance of such prey varies drastically, and it is expected that population changes in prey species will affect the feeding habits of dolphins and porpoises. Population change in prey would provide a good opportunity to study the foraging strategy of predators.

A major population decline of Sardinops melanostictus (Japanese pilchard) occurred near Japan in the late 1980s (Watanabe et al. 1995). In the Sea of Japan and Sea of Okhotsk, the commercial catch of $S$. melanostictus declined from about $10000 \mathrm{t}$ in 1990 to $1000 \mathrm{t}$ in

- Present address: National Research Institute of Far Seas Fisheries, Orido, Shimizu, Shizuoka 424-8633, Japan.

E-maiI: ohizumi@enyo.affrc.go.jp
1993. S. melanostictus was the main summer prey for Dall's porpoise Phocoenoides dalli in the southern Sea of Okhotsk in 1988 (Walker 1996); however, the effect of this population decline on the feeding habits of Dall's porpoises has not been examined.

Dall's porpoises are widely distributed in the northern North Pacific and adjacent waters, including the Bering Sea, Sea of Okhotsk and Sea of Japan (Houck \& Jefferson 1999). A population of Dall's porpoises, which was investigated by Walker (1996), is distributed off the Tajima area in the Sea of Japan in winter, and migrates to the northeastern Sea of Japan and southern Sea of Okhotsk around Hokkaido in summer (Noguchi 1946, Amano \& Kuramochi 1992).

The major prey of Dall's porpoises varies among populations and local habitats. Dall's porpoises in offshore regions feed on mesopelagic fishes and squids, but those in nearshore waters feed on various prey common 
to the continental shelves (Walker 1996). Dall's porpoises in the northwestern North Pacific feed primarily on myctophid fishes and gonatid squids (Wilke et al. 1953, Wilke \& Nicholson 1958, Kuramochi et al. 1993).

The biogeography of the Sea of Japan and Sea of Okhotsk differs from that of the North Pacific, particularly in that myctophid fishes (Nishimura 1974) and squids of the genus Gonatus (Okiyama 1993) are not found in the Sea of Japan. As a result, the prey of Dall's porpoises in the Sea of Japan and Sea of Okhotsk are different from those in the North Pacific. Changes in the feeding habits of Dall's porpoises after the population decline in Sardinops melanostictus will also presumably occur.

In this paper, we compare the prey composition of Dall's porpoises before and after the Sardinops melanostictus population decline using data collected from 6 surveys in coastal areas of the northeastern Sea of Japan and southern Sea of Okhotsk. Fluctuations in the prey items are compared to the catch statistics of local fisheries. Foraging strategies are discussed in light of prey switching.

\section{MATERIALS AND METHODS}

Field surveys. Dall's porpoises were collected in the Sea of Japan (JS) in May of 1989, 1995 and 1996, and in the Sea of Okhotsk (OK) in June 1988, October 1994, and August 1995 (Fig. 1). In these areas, porpoise are fished, and we used the catch. Dall's porpoises were captured by hand-harpoon. Stomachs were removed intact, the esophageal and duodenal ends were tied, and stomachs were then frozen for later analyses. Gonads were removed and fixed in $10 \%$ neutral formaldehyde solution. A total of 150 stomachs were examined. These included 69 (42 male, 27 female) from the JS and 81 (50 male, 31 female) from the OK.

Laboratory analyses. In the laboratory, the stomachs were thawed, and the forestomachs were separated from the other chambers. Each forestomach was opened, and its contents were placed in a plastic pan. The inner walls of the forestomachs were rinsed carefully, and a pan was used to collect all prey remnants. Only the forestomach contents were examined, herefater referred to as 'stomach contents'.

Fish sagittal otoliths and squid lower beaks were removed from the stomach contents. Undigested and half-digested fishes, fish skull containing otoliths, and squid buccal masses with beaks were also removed. Identifiable prey remains were sorted secondarily into taxonomic groups by comparison with H.O.'s otolith collection and the cephalopod beak collection at the National Science Museum, Tokyo. The cephalopod beak and otolith references Clarke (1986), Kubodera \&

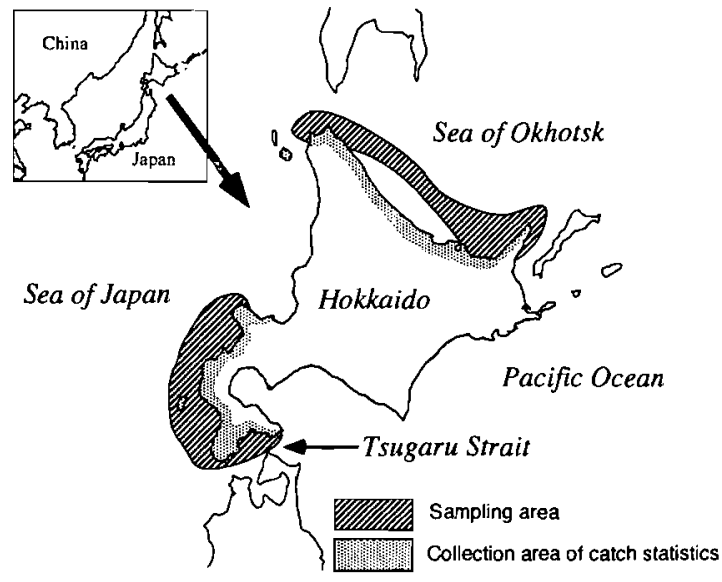

Fig. 1. Sampling areas for Dall's porpoises and catch statistics for prey species

Furuhashi (1987) and Smale et al. (1995) were also consulted. Where possible, undigested and partially digested prey remains were identified to species based on external morphology.

Lower rostral lengths (LRL) of squid beaks were measured to the nearest $0.1 \mathrm{~mm}$ with vernier calipers or a profile projector $(\times 10)$. Regressions listed in Table 1 were used to estimate dorsal mantle lengths (DML) and body weights from LRL. We did not measure all lower beaks. When large numbers of 1 prey species were present, a subsample composed of at least $10 \%$ of the total number was measured. All samples were selected from undamaged isolated beaks.

Standard body lengths of fishes were measured for undigested and, if possible, partially digested fishes to the nearest $1 \mathrm{~mm}$. Many of the partially digested Engraulis japonicus (Japanese anchovy) had lost their cranial portions. Therefore, lengths from the first cervical vertebra to the end of the hypural were measured. These lengths were then multiplied by the coefficient 1.185 derived from the intact $E$. japonicus to estimate SL. All Theragra chalcogramma (walleye pollock) were at least half digested and broken into 2 or 3 pieces, and Maurolicus muelleri were digested completely, with only otoliths remaining. Therefore, sagittal otolith lengths were used to estimate the fork lengths of $T$. chalcogramma and SL of $M$. muelleri according to Frost \& Lowry (1981) and Smale et al. (1995), respectively. Sagittal otolith lengths were measured to the nearest $0.1 \mathrm{~mm}$ with a profile projector. Body weights of fishes were estimated from the relationships shown in Table 1. The total contribution by weight of each prey species was calculated by multiplying the average estimated weight by the prey number of each species present.

Caloric values of prey were obtained from the literature (Table 2). Total caloric contributions were calcu- 
Table 1. Relationships between measured variables and body length or body weight. DML: dorsal mantle length; LRL: lower rostral length; BW: body weight; FL: fork length; SL: standard body length; OL: otolith length

\begin{tabular}{|c|c|c|c|c|c|c|}
\hline Species & Regression & $y$ & $x$ & $\mathrm{r}^{2}$ & $\mathbf{n}$ & Source \\
\hline $\begin{array}{l}\text { Squids } \\
\text { Gonatopsis borealis }\end{array}$ & $\begin{array}{c}y=35.779 x+17.036 \\
\ln y=2.037 \ln x+2.145\end{array}$ & $\begin{array}{l}\mathrm{DML}(\mathrm{mm}) \\
\mathrm{BW}(\mathrm{g})\end{array}$ & $\begin{array}{l}\text { LRL (mm) } \\
\text { LRL (mm) }\end{array}$ & $\begin{array}{l}0.94 \\
0.93\end{array}$ & $\begin{array}{l}50 \\
50\end{array}$ & Kubodera (1986) \\
\hline Berryteuthis magister & $\begin{array}{l}y=46.214 x-14.021 \\
\ln y=2.66 \ln x-8.563\end{array}$ & $\begin{array}{l}\text { DML (mm) } \\
\text { BW (g) }\end{array}$ & $\begin{array}{l}\text { LRL (mm) } \\
\operatorname{DML}(\mathrm{mm})\end{array}$ & $\begin{array}{l}0.91 \\
0.99\end{array}$ & $\begin{array}{l}31 \\
32\end{array}$ & Walker (1996) \\
\hline Gonatus onyx & $\begin{array}{c}y=19.02 x+12.82 \\
\ln y=2.13 \ln x+0.086\end{array}$ & $\begin{array}{c}\mathrm{DML}(\mathrm{mm}) \\
\mathrm{BW}(\mathrm{g})\end{array}$ & $\begin{array}{l}\text { LRL }(\mathrm{mm}) \\
\operatorname{LRL}(\mathrm{mm})\end{array}$ & $\begin{array}{l}0.72 \\
0.82\end{array}$ & $\begin{array}{l}\text { NA } \\
\text { NA }\end{array}$ & Wolff (1984) \\
\hline Other Gonatidae spp. & $\begin{aligned} y & =42.87 x-43.4 \\
\ln y & =3.33 \ln x-0.655\end{aligned}$ & $\begin{array}{c}\text { DML (mm) } \\
\text { BW }(\mathrm{g})\end{array}$ & $\begin{array}{l}\text { LRL (mm) } \\
\text { LRL (mm) }\end{array}$ & $\begin{array}{l}\text { NA } \\
\text { NA }\end{array}$ & $\begin{array}{l}17 \\
20\end{array}$ & $\begin{array}{l}\text { Clarke (1986), obtained } \\
\text { from Gonatus spp. }\end{array}$ \\
\hline Taonius pavo & $\begin{aligned} y & =61.43 x-12.3 \\
\ln y & =2.19 \ln x+0.786\end{aligned}$ & $\begin{array}{l}\text { DML (mm) } \\
\text { BW (9) }\end{array}$ & $\begin{array}{l}\text { LRL (mm) } \\
\text { LRL (mm) }\end{array}$ & $\begin{array}{l}\text { NA } \\
\text { NA }\end{array}$ & $\begin{array}{l}72 \\
74\end{array}$ & $\begin{array}{l}\text { Clarke (1986), obtained } \\
\text { from Taoniinae spp. }\end{array}$ \\
\hline Todarodes pacificus & $\begin{array}{c}y=37.44 x+18.53 \\
\ln y=2.64 \ln x+1.11\end{array}$ & $\begin{array}{l}\mathrm{DML}(\mathrm{mm}) \\
\mathrm{BW}(\mathrm{g})\end{array}$ & $\begin{array}{l}\text { LRL }(\mathrm{mm}) \\
\text { LRL }(\mathrm{mm})\end{array}$ & $\begin{array}{l}0.97 \\
0.98\end{array}$ & $\begin{array}{l}\text { NA } \\
\text { NA }\end{array}$ & Wolff $(1984)$ \\
\hline Watasenia scintillans & $\begin{array}{c}y=40.55 x-2.66 \\
\ln y=2.49 \ln x+0.847\end{array}$ & $\begin{array}{l}\text { DML (mm) } \\
\text { BW }(g)\end{array}$ & $\begin{array}{l}\text { LRL }(\mathrm{mm}) \\
\text { LRL }(\mathrm{mm})\end{array}$ & $\begin{array}{l}0.93 \\
0.92\end{array}$ & $\begin{array}{l}\text { NA } \\
\text { NA }\end{array}$ & $\begin{array}{l}\text { Wolff (1964), obtained } \\
\text { from Abraliopsis felis }\end{array}$ \\
\hline $\begin{array}{l}\text { Fishes } \\
\text { Theragra chalcogramma }\end{array}$ & $\begin{aligned} y & =2.246 x-0.510 \\
y & =3.175 x-9.770 \\
\ln y & =2.906 \ln x-4.867\end{aligned}$ & $\begin{array}{l}\text { FL }(\mathrm{cm}) \\
\text { FL }(\mathrm{cm}) \\
\text { BW }(\mathrm{g})\end{array}$ & $\begin{array}{c}\text { OL }(\mathrm{mm})<10.0 \mathrm{~mm} \\
\mathrm{OL}(\mathrm{mm})>10.0 \mathrm{~mm} \\
F L(\mathrm{~cm})\end{array}$ & $\begin{array}{l}0.98 \\
0.97 \\
0.998\end{array}$ & $\begin{array}{c}158 \\
98 \\
109\end{array}$ & Frost \& Lowry (1981) \\
\hline Maurolicus muelleri & $\begin{array}{l}\ln y=0.962 \ln x+3.156 \\
\ln y=3.097 \ln x-1.833\end{array}$ & $\begin{array}{l}\mathrm{SL}(\mathrm{mm}) \\
\mathrm{BW}(\mathrm{g})\end{array}$ & $\begin{array}{l}\text { OL }(\mathrm{mm}) \\
\text { OL }(\mathrm{mm})\end{array}$ & $\begin{array}{l}0.76 \\
0.62\end{array}$ & $\begin{array}{l}90 \\
87\end{array}$ & Smale et al. (1995) \\
\hline Sardinops melanostictus & $\ln y=3.15 \ln x-12.129$ & $\mathrm{BW}(\mathrm{g})$ & $\mathrm{SL}(\mathrm{mm})$ & 0.99 & 14381 & Walker (1996) \\
\hline Pleurogrammus azonus & $\ln y=3.177 \ln x-12.068$ & BW $(g)$ & $\mathrm{SL}(\mathrm{mm})$ & NA & 130 & Sasaki (1987) \\
\hline Ammodytes personatus & $\log y=2.27 \log x-1.343$ & $B W(g)$ & $\mathrm{SL}(\mathrm{cm})$ & 0.62 & 10 & Present study \\
\hline Engraulis japonicus & $\log y=3.40 \log x-2.378$ & BW (g) & $\mathrm{SL}(\mathrm{cm})$ & 0.85 & 18 & Present study \\
\hline
\end{tabular}

lated from these energy values and estimated prey weights.

The reproductive condition of each Dall's porpoise sample was determined by examining its gonads. Females with ovarian corpora and males in which spermatogenesis was observed in more than half of the testicular tubules in histological sections were classified as mature (Amano \& Kuramochi 1992).

Data processing of catch statistics. The catch statistics of Sardinops melanostictus, Ammodytes personatus (Japanese sandlance), Pleurogrammus azonus (greenling), and Therogra chalcogramma were analyzed. These data included monthly records of catch weight at 70 local fishery cooperative unions in 1988, 1989, 1994 and 1995. Data were recorded for all types of fishing gear, but only local set-net fisheries, local common right fisheries including small set-nets and gill nets, and free fisheries including mainly angling were selected to examine local catch fluctuations. The statistics were collected from the same area as the sampling area of Dall's porpoises (Fig. 1).
Table 2. Caloric values of prey species

\begin{tabular}{|lcl|}
\hline Species & Caloric value $\left(\mathrm{kJ} \mathrm{g}^{-1}\right)$ & Source \\
\hline Sardinops melanostictus & 11.76 & Walker (1996) \\
Engraulis japonicus & 8.28 & Resources Council (1982) \\
Ammodytes personatus & 4.44 & Resources Council (1982) \\
Theragra chalcogramma & 4.64 & Perez (1994) \\
Pleurogrammus azonus & 6.61 & Perez \& Bigg (1986) \\
Berryteuthis magister & 5.52 & Perez (1994) \\
Gonatopsis borealis & 4.69 & Perez (1994) \\
Other Gonatidae & 3.78 & Clarke et al. (1985) \\
Taonius pavo & 1.69 & Clarke et al (1985) \\
Todarodes pácificus & 4.01 & Clarke et al (1985) \\
Watasenia scintillans & 4.60 & Resources Council (1982) \\
a'Moisture content for E. japonicus in Resources Council (1982) was corrected \\
${ }^{\mathrm{d}}$ Gonatus sp. in Clarke et al. (1985) & \\
${ }^{\mathrm{c}}$ Teuthowenia sp. in Clarke et al. (1985) & \\
${ }^{\mathrm{d}}$ Todarodes sagittatus in Clarke et al. (1985) & \\
\end{tabular}

\section{RESULTS}

\section{Porpoises examined}

Average body lengths for Dall's porpoises in the JS ranged from 177.0 to $184.1 \mathrm{~cm}$ for females, and from 
Table 3. Sample composition of Dall's porpoises caught from the Sea of Japan and Sea of Okhotsk. F: female; M: male

\begin{tabular}{|c|c|c|c|c|c|c|c|c|c|c|c|c|c|}
\hline & \multicolumn{6}{|c|}{ _ Sea of Japan } & \multicolumn{6}{|c|}{ Sea of Okhotsk } & \multirow[t]{3}{*}{ Total } \\
\hline & \multicolumn{2}{|c|}{ May 1989} & \multicolumn{2}{|c|}{ May 1995} & \multicolumn{2}{|c|}{ May 1996} & \multicolumn{2}{|c|}{ Jun 1988} & \multicolumn{2}{|c|}{ Oct 1994} & \multicolumn{2}{|c|}{ Aug 1995} & \\
\hline & $\mathrm{F}$ & M & $\mathrm{F}$ & $M$ & $\mathrm{~F}$ & $\mathrm{M}$ & $\mathrm{F}$ & M & $\mathrm{F}$ & $M$ & $\mathrm{~F}$ & $\mathrm{M}$ & \\
\hline Average body length $(\mathrm{cm})$ & 178.5 & 194.3 & 184.1 & 181.3 & 177.0 & 192.0 & 187.4 & 195.1 & 179.6 & 187.4 & 186.5 & 202.3 & 189.0 \\
\hline SD & 12.0 & 8.2 & 13.6 & 18.0 & 11.7 & 13.7 & 7.0 & 12.7 & 7.1 & 10.8 & 7.9 & 13.9 & 14.4 \\
\hline No. of sexually immature porpoises & s 2 & 2 & 11 & 15 & 11 & 9 & 4 & 4 & 4 & 10 & 4 & 10 & 86 \\
\hline No. of sexually mature porpoises & 0 & 5 & 1 & 3 & 2 & 8 & 16 & 9 & 0 & 3 & 2 & 14 & 63 \\
\hline No. of unidentified porpoises & 0 & 0 & 0 & 0 & 0 & 0 & 0 & 0 & 1 & 0 & 0 & 0 & 1 \\
\hline Total number of porpoises & 2 & 7 & 12 & 18 & 13 & 17 & 20 & 13 & 5 & 13 & 6 & 24 & 150 \\
\hline
\end{tabular}

181.3 to $194.3 \mathrm{~cm}$ for males. Proportions of sexually mature porpoises varied, but most females were immature (Table 3).

Average body lengths in the OK ranged from 179.6 to $187.4 \mathrm{~cm}$ for females and from 187.4 to $202.3 \mathrm{~cm}$ for males. Sexually mature individuals were more numerous in the OK than in the JS; however, few were collected in October 1994 (Table 3).

\section{Composition of prey species}

A total of 29 types of prey, including 6 identified fish species and 12 identified cephalopod species, were found in specimens from the JS (Table 4). In 1989, Sardinops melanostictus was the dominant prey by number, total mass and caloric contribution; all porpoises fed on S. melanostictus. Theragra chalcogramma was the next major fish prey; it was consumed by $44 \%$ of the porpoises. In 1995 and 1996, however, very few $S$. melanostictus were found in the stomach contents. During these years, porpoises fed largely on $T$. chalcogramma. Other prey species, such as Engraulis japonicus, Ammodytes personatus, Pleurogrammus azonus, Todarodes pacificus (Japanese common squid), and Berryteuthis magister (magistrate armhook squid), were also relatively important as supplemental prey. In 1996 the consumption of $T$. chalcogramma was lower, and the prey composition was more diversified than in 1995. Percent occurrences of prey in 1996 were not prominently high, excluding $77 \%$ for Gonatidae juveniles (G-A-1) which were not so important in weight and calory contributions. This also indicates diversification of prey in 1996. Mesopelagic fishes other than Maurolicus muelleri were not found. Gonatus squids that have not been reported to occur in the JS were found in the stomach contents of porpoises from the JS. This may have been because the sampling area in the JS is near the Tsugaru Strait, which connects the JS to the Pacific Ocean.

In the $\mathrm{OK}, 37$ prey types were found, including 14 fish species and 11 squid species (Table 5). In 1988, Sardinops melanostictus was the most important prey, and Berryteuthis magister was the next most important prey. In 1994, S. melanostictus was not observed, and Engraulis japonicus and B. magister were dominant. In 1995, Berryteuthis magister was the dominant prey, and neither $S$. melanostictus nor E. japonicus were found. Bathylagid fishes formed the largest proportion of fish prey, but were consumed by fewer than onethird of the porpoises. Unlike the JS data, mesopelagic fishes such as myctophids and bathylagids were found, but their numerical contributions were small. We could not estimate the amount of these species consumed, but assume it was small since these fishes are relatively small, and were numerically unimportant.

\section{Number of freshly consumed prey in reference to time of day}

The number of prey with undigested flesh showed species-specific distributions in relation to the time of catch (Fig. 2). Numerous Sardinops melanostictus, Engraulis japonicus and Todarodes pacificus were found in stomachs collected throughout the day, and bathylagid fishes and gonatid squids other than Berryteuthis magister were found in those collected in the morning. Many Pleurogrammus azonus and B. magister were found in samples collected in the morning and before dusk. Partially digested Theragra chalcogramma were found in samples collected throughout the day, but in fewer numbers than those of other species of fresh prey.

\section{Prey size}

Fish prey for all surveys ranged in size from 1.9 (Maurolicus muelleri) to $52.5 \mathrm{~cm}$ (Theragra chalcogramma) (Fig. 3). Smaller fishes occurred in large numbers. Three peaks are apparent in the frequency distribution of fish size. $M$. muelleri, which had a $2.5 \mathrm{~cm}$ mean body length, formed the first peak. Bathylagid fishes and Engraulis japonicus formed the second peak at $13 \mathrm{~cm}$. Sardinops melanostictus, Ammodytes personatus and Pleurogram- 


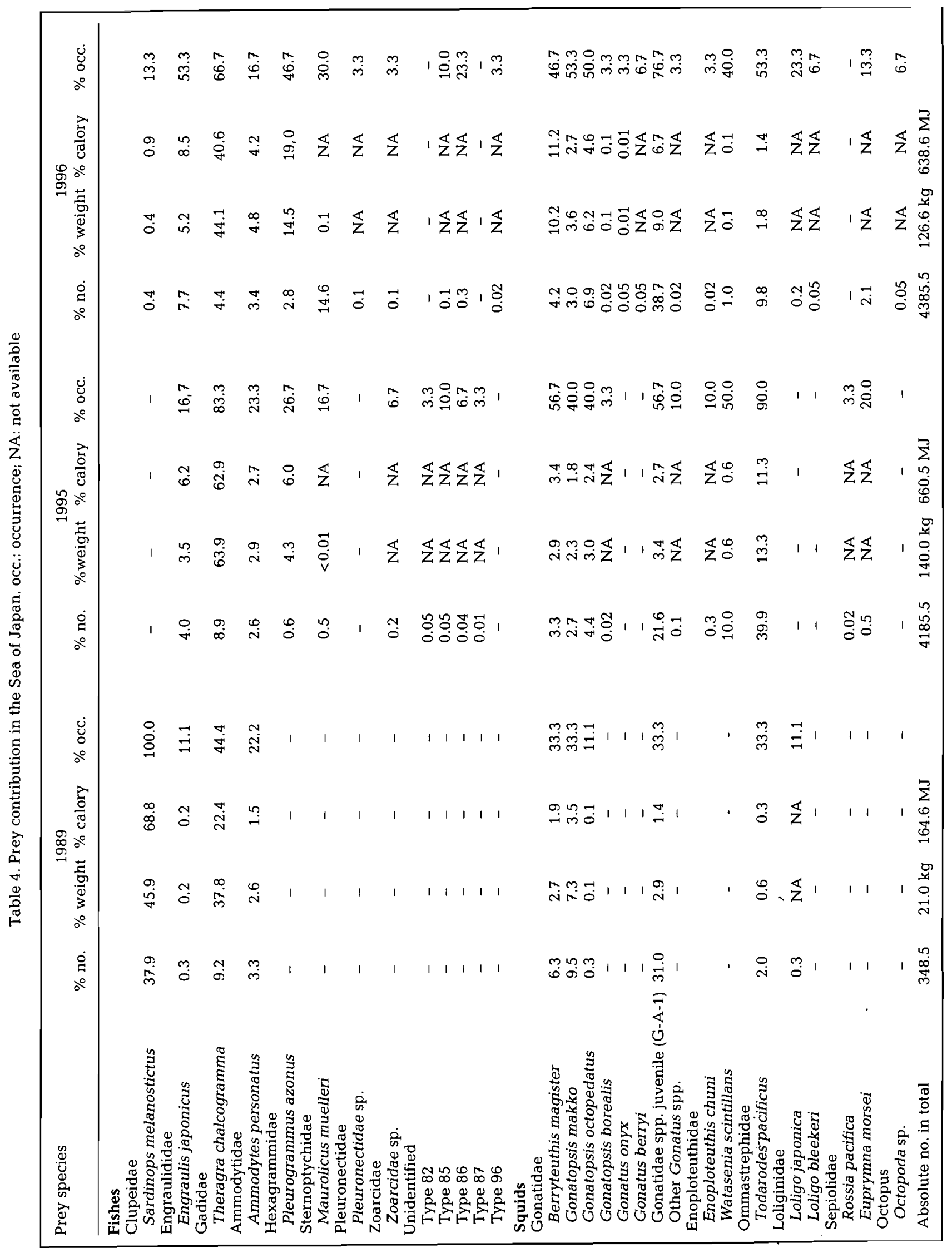




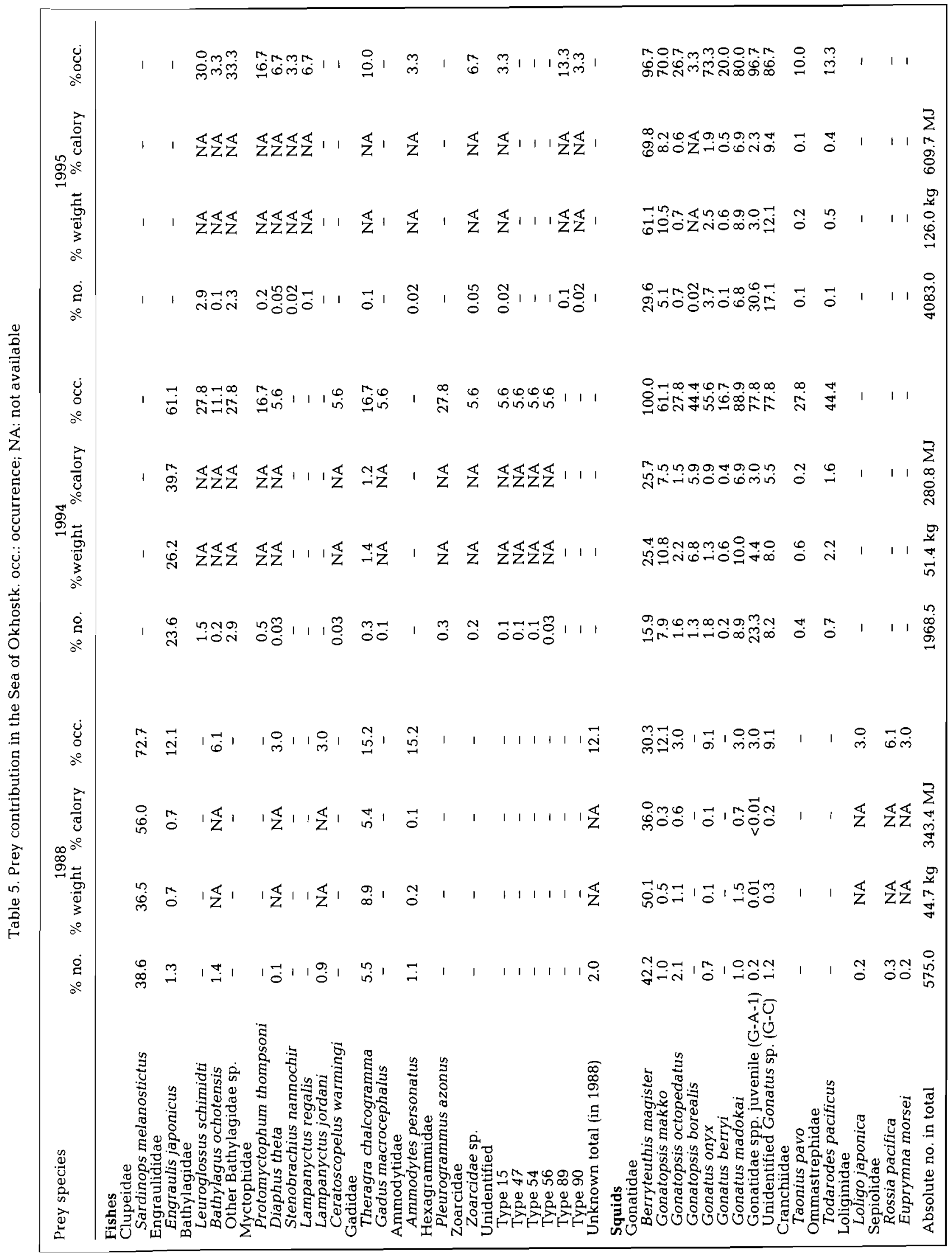


mus azonus formed the third peak at 18 to $22 \mathrm{~cm}$. With a mean body length of $34 \mathrm{~cm}, T$. chalcogramma was represented in all body length categories over $29 \mathrm{~cm}$.

Dall's porpoises tended to also feed on smaller squids; however, the size range was narrower than that of the fish prey (Fig. 3). The prey DML peaked at $3 \mathrm{~cm}$. Juvenile Gonatidae spp. (G-A-1) were the most abundant squids in this size class. Most ranged in size from 2 to $12 \mathrm{~cm}$. Many species were distributed in this size range and had mean DML sizes of about $10 \mathrm{~cm}$. The mean sizes of Gonatus berryi, Gonatopsis borealis and Taonius pavo were larger.

The frequency distributions of estimated sizes for Berryteuthis magister were wide (Fig. 4); they typically ranged from 5 to $20 \mathrm{~cm}$, except for samples in the JS in 1989. Distributions in the late 1980 s showed a single size mode, but those in the 1990s showed several size modes.

\section{Variations in catch statistics versus variation in stomach contents}

The commercial fisheries catch statistic patterns sometimes differed from feeding patterns of Dall's por-

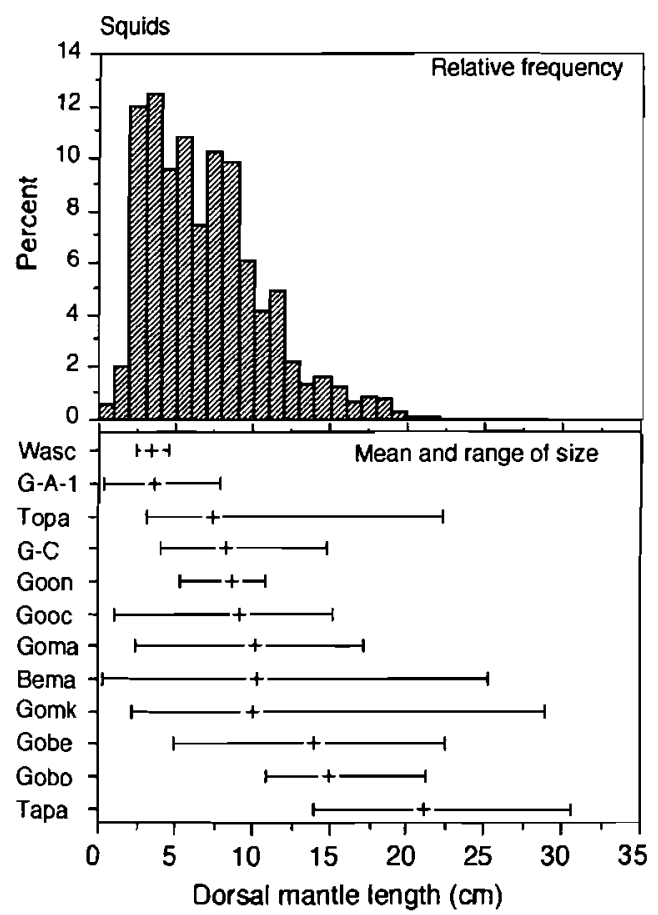

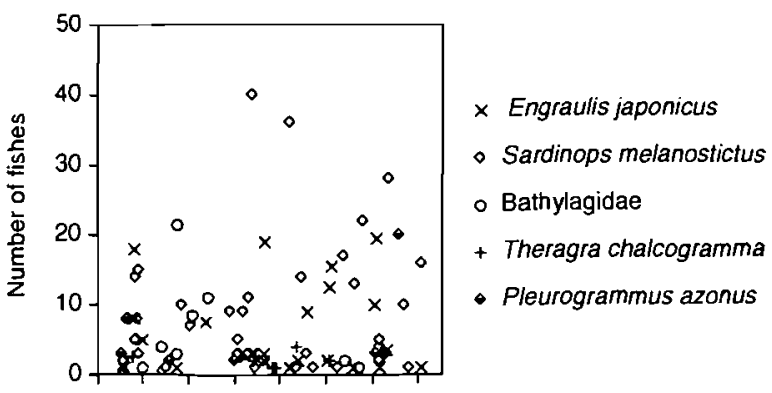

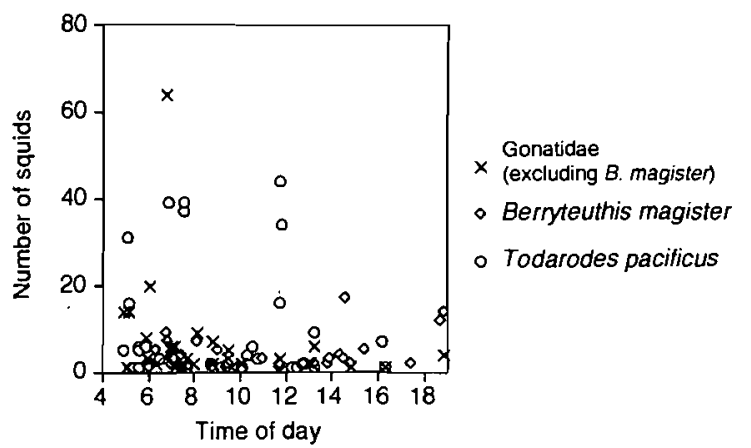

Fig. 2. Distributions of fresh prey in the daytime. Data from the Sea of Japan and Sea of Okhotsk are pooled

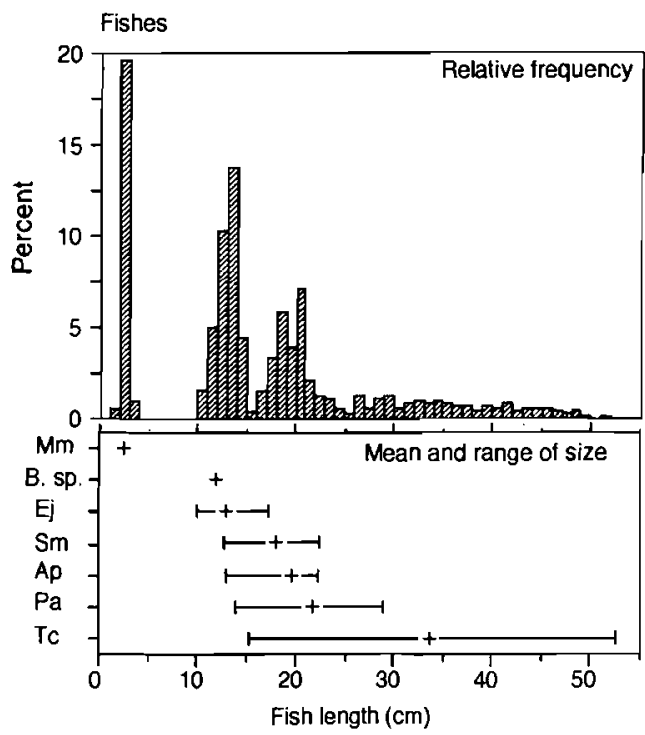

Wasc: Watasenia scintillans, G-A-1: Gonatidae juvenile, Topa: Todarodes pacificus, G-C: unidenlified Gonatus, Goon: Gonatus onyx, Gooc: Gonatopsis octopedatus, Goma: Gonatus madokai, Bema: Bernteuthis magister Gomk: Gonatopsis makko, Gobe: Gonatus berryi. Gobo: Gonatopsis borealis, Tapa: Taonius pavo, Mm: Maurolicus muelleri, B. sp: Bathylagidae, Ej: Engraulis japonicus, Sm: Sardinops melanostictus, Ap: Ammodytes personatus, $\mathrm{Pa}$ : Pleurogrammus azonus, Tc: Theragra chalcogramma

Fig. 3. Estimated size of prey species. Data from the Sea of Japan and Sea of Okhotsk are pooled. The number of measured subsamples varied among species. Therefore, relative frequency distribution of body lengths of fishes and squids at intervals of $1 \mathrm{~mm}$ for each species were weighted by the number of each prey species found in the forestomach, and rounded up to the nearest integer. These weighted frequencies were used to describe the total frequency distributions for squids or fishes 


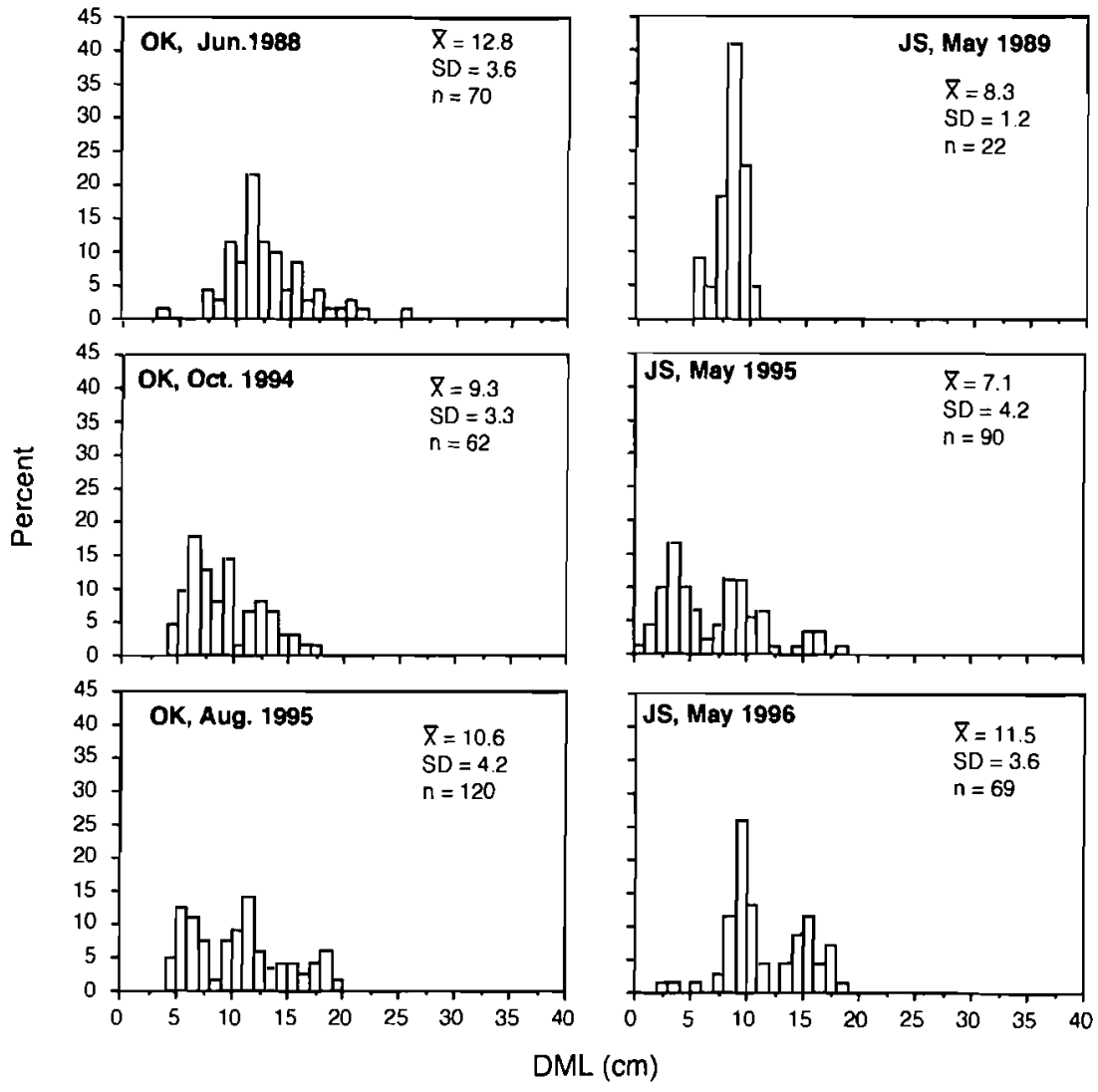

Fig. 4. Frequency distribution of estimated dorsal mantle length (DML) of Berry. teuthis magister. JS: Sea of Japan; OK: Sea of Okhotsk

The caloric value of Sardinops melanostictus used in this study was cited from Walker (1996), who used the fat content value in Kizevetter (1971). Walker (1996) compared the differences in the literature to the fat content of $S$. melanostictus and concluded that Kizevetter's value is more representative for $S$. melanostictus, because the fat content was based on a large sample size analyzed over a 5 yr period. The caloric values of Theragra chalcogramma and Berryteuthis magister (Perez 1994) and Engraulis japonicus (Oya et al. 1937) do not appear to exhibit variance due to body length.

Because of differences in the digestibility among prey species, comparison of weight and caloric contribution obtained from stomach contents containing mixed species may underestimate the more easily digested prey species. Crawford (1981) suggested that fishes are digested more rapidly than squids since fish muscle tissue tends to flake apart. However, Bigg \& Fawcett (1985) noted that the squid Loligo opalescens was diges-

poises (Fig. 5). For example, Theragra chalcogramma in the OK was less important as prey than in the JS, although catch statistics in both seas were similar. Pleurogrammus azonus was caught in large numbers in both seas, but was not an important prey, especially in the OK. In the OK in June 1988, porpoises fed on relatively few Ammodytes personatus, which had a total catch in the fishery of about $2900 \mathrm{t}$. However, Dall's porpoises in early summer in the JS fed more commonly on $A$. personatus, while few $A$. personatus were caught by fisheries. In contrast to these inconsistencies between catch statistics and stomach contents, Sardinops melanostictus was the most common prey when they were abundant in the late 1980 s.

\section{DISCUSSION}

\section{Possible biases}

The caloric value of a prey species may vary seasonally and with body size due to variation in fat content. This variation will affect the energy intake calculation (Gaskin 1982, Mårtensson et al. 1996, Walker 1996). ted much faster than herring Clupea pallasi both in an in vitro experiment of digestion using an artificial digestive solution and in a seal stomach. A similar artificial digestion experiment showed that the digestion time of squids $L$. opalescens and Todaropsis eblanae is within the range of the digestion time of various other fishes (Sekiguchi 1994). Although digestion time differs among species, the time range of digestion for fishes and squids overlaps.

Differences among fish species in otolith digestion must also be considered. Härkönen (1986) noted that otoliths of gadid fishes are among the most resistant to digestion. Thus otoliths of Theragra chalcogramma may accumulate in stomachs; so the contributions of $T$. chalcogramma may have been overestimated.

\section{Fresh prey and time of feeding}

By comparing of the presence of freshly ingested intact or nearly intact prey with the time of collection, inferences can be made about time of feeding on different prey species (Walker 1996). Walker (1996) reported daytime foraging of Dall's porpoises on 

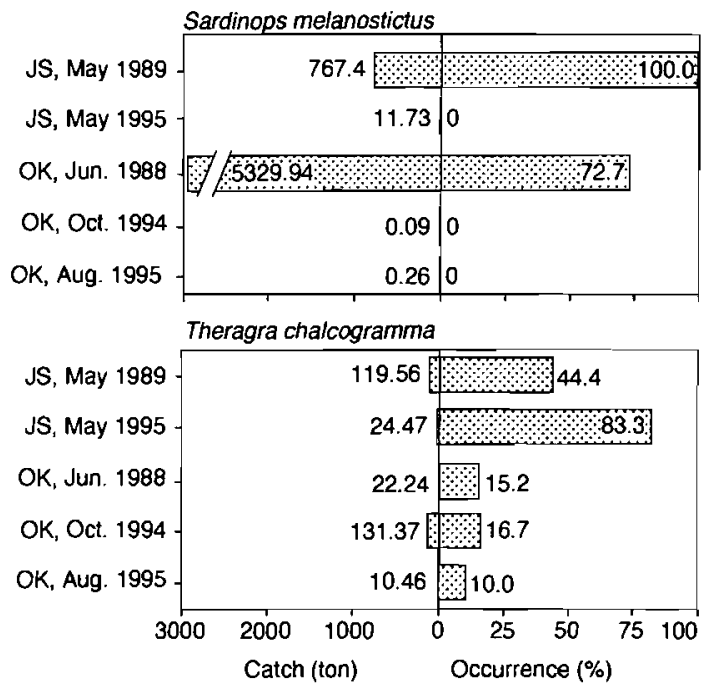
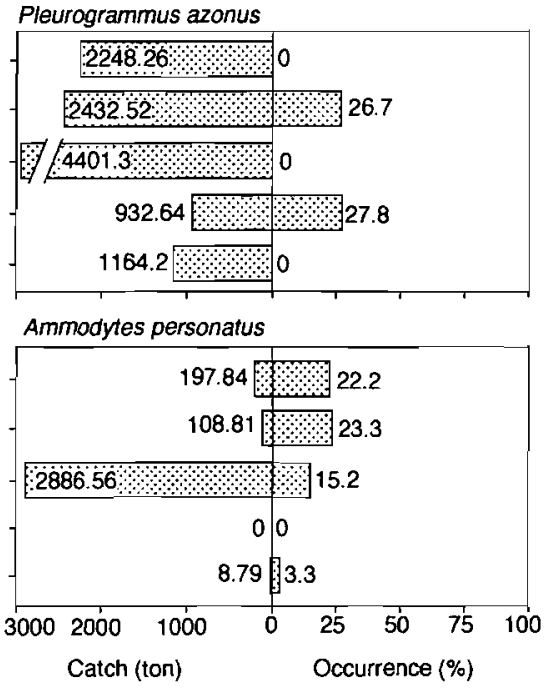

Fig. 5. Comparison of catch statistics from local fisheries and prey occurrences in the stomach contents. JS: Sea of Japan; OK: Sea of Okhotsk
Sardinops melanostictus in the OK in 1988, and our results support this. Findings of fresh $S$. melanostictus, Engraulis japonicus and Todarodes pacificus throughout the daytime suggest Dall's porpoises fed on these prey items in daylight hours. The absence of $T$. pacificus in the afternoon is due to the lack of sampling due to rough sea conditions in the JS in 1995. In contrast, the findings of fresh Pleurogrammus azonus and Berryteuthis magister in the morning and at dusk suggest that they were eaten around twilight or during the night. Similar conclusions could be made for gonatid squids and bathylagid fishes that were found in morning samples.

These species-specific times of foraging are probably related to habitat-use patterns of the prey. Dall's porpoises fed on epipelagic species such as Sardinops melanostictus, Engraulis japonicus and Todarodes pacificus throughout the daylight hours. However, Dall's porpoises probably feed on mesopelagic species such as gonatid squids and bathylagid fishes when they ascend into the surface waters at night. Based on behavioral observations, Amano et al. (1998) concluded that the feeding time of Dall's porpoises changes according to habitat use of prey species. The present stomach content analysis results support this conclusion.

\section{Size range of prey}

Dall's porpoises fed on a wide size range of prey, but they preferred smaller prey species. Walker (1996) and Crawford (1981) reported maximum prey sizes of 60 and $48 \mathrm{~cm}$ for fishes respectively; the largest prey in the present study was $52 \mathrm{~cm}$. About 50 to $60 \mathrm{~cm}$ is probably the upper limit of the prey size for Dall's porpoises.
In general, adult and juvenile Berryteuthis magister with a DML of over $10 \mathrm{~cm}$ are distributed on the slopes of continental shelves at depths of 200 to $1000 \mathrm{~m}$ (Naito et al. 1977). $B$. magister smaller than $15 \mathrm{~cm}$ DML are distributed near the bottom at depths shallower than $500 \mathrm{~m}$ in the southern OK (Kubodera 1982). The vertical distribution range for $B$. magister in the eastern Etorohu (Iturup) Islands is 300 to $600 \mathrm{~m}$ (Naito et al. 1977). On the other hand, juvenile $B$. magister whose DML is 14 to $15 \mathrm{~cm}$ in the JS off western Hokkaido occur at 500 to $800 \mathrm{~m}$ (Naito et al. 1977). The continental shelf in western Hokkaido is narrow and the slope drops down steeply to depths greater than $1000 \mathrm{~m}$ at a few kilometers off the coast. Dall's porpoises fed on juvenile and adult $B$. magister, which suggests they foraged near the bottom layer. However, due to the steep slope in the JS, B. magister may inhabit an even deeper depth, which may account for the fewer numbers of $B$. magister eaten by Dall's porpoises in this region.

Adult Pleurogrammus azonus typically inhabit rocky reef environments. The mean size of $P$. azonus $(22.3$ $\mathrm{cm}, \mathrm{SD}=3.7, \mathrm{n}=30$ ) eaten by porpoises has been reported as the size of the 1 yr age class (Nagasawa \& Torisawa 1991). In spring, yearling $P$. azonus often concentrate at the surface to feed on zooplankton (Nagasawa \& Torisawa 1991). The limited size range of $P$. azonus found in the stomach contents suggests that Dall's porpoises probably fed on $P$. azonus in the surface of waters in the JS in spring.

\section{Prey switching and a possible foraging strategy}

Walker (1996) reported that Sardinops melanostictus was the main prey from the OK in August 1988, while 
we found Berryteuthis magister to be the main prey in August 1995. This suggests that $B$. magister inhabit the OK in August, but Dall's porpoises fed on few of them in 1988. Because the commercial fisheries catch statistics for Engraulis japonicus were incomplete, seasonal variation of the availability in $E$. japonicus is unknown. There are no catch statistics for $B$. magister. Still we could not evaluate the seasonality in prey change from $E$. japonicus to $B$. magister that was observed between October 1994 and August 1995.

The estimated abundance by cohort analysis of Theragra chalcogramma in the JS off western Hokkaido was 4.2 billion individuals in 1989, and 1.7 billion individuals in 1994 (Mizuno \& Miyake 1996). Recent population declines have occurred in the JS for both Sardinops melanostictus and T. chalcogramma. In the JS, unlike the Pacific, Dall's porpoises have only limited opportunities to feed on mesopelagic prey, because mesopelagic fishes and squids have limited distribution in the JS (Nishimura 1974). As a result of the population declines of $S$. melanostictus and $T$. chalcogramma, and of the deeper distribution of Berryteuthis magister, recent available food resources in the JS may have became limited. This probably explains why Dall's porpoises fed more on supplemental prey species such as Engraulis japonicus, Ammodytes personatus, Pleurogramus azonus and Todarodes pacificus in the JS. Dall's porpoises in the JS might have had to diversify their prey especially in 1996.

Although there are some physical factors involved, such as appropriate prey size for basic prey selection, assuming that Dall's porpoises are not selective feeders seeking specific prey and feed on whatever appropriate prey they encounter, the composition and proportion of prey items should reflect the abundance of prey species in the environment. However, the proportional variation of actual prey items was not always consistent with catch statistics.

The prey switching that occurred between the 1980 s and 1990 s could be summarized as a switching from epipelagic to benthopelagic prey. This switching in the JS was not affected by the abundance of benthopelagic Thergra chalcogramma. This suggests that Dall's porpoises have an epipelagic preference for foraging. Dall's porpoises fed on mesopelagic prey that perform diel vertical migrations. This also suggests a preference for epipelagic foraging. An epipelagic preference for foraging has also been observed in harbor seals Phoca vitulina in Scotland. Tollit et al. (1997) reported that the harbor seal's tendency to feed on benthopelagic fishes was correlated with a decrease in abundance of epipelagic fishes and not on the abundance of benthopelagic fishes. Epipelagic foraging has the obvious advantages of saving time and energy, and facilitates efficient energy intake and utilization.
When Sardinops melanostictus are not available, Dall's porpoises seeking food presumably must dive to deeper waters, where they will encounter $T$. chalcogramma and Berryteuthis magister in the JS and OK. In the JS, the deeper habitat of $B$. magister may prevent Dall's porpoises from feeding on them. $T$. chalcogramma migrates vertically between the mesopelagic layer and the bottom (Maeda 1974). In the JS in May, it is distributed at the bottom at depths of about $250 \mathrm{~m}$ (Maeda 1974). Dall's porpoises in the JS might encounter $T$. chalcogramma more often than B. magister at mid-depths and near the relatively shallow bottom.

Acknowledgements. We thank Mr S. Sasaki, Mr Y. Kamoya, Mr K. Shibuta, Mr T. Ogasawara and other crews of hand harpoon fishery vessels who helped us in the field study. Prof. K. Kawaguchi, Dr T. Kubodera, and Dr T. Matsuishi provided information on the prey species. The Hokkaido Central Fisheries Experimental Station in Yoichi provided the catch statistics. Dr J. Bower and Dr R. L. Brownell Jr. reviewed the manuscript.

\section{LITERATURE CITED}

Amano M, Kuramochi T [1992) Segregative migration of Dall's porpoise (Phocoenoides dalli) in the Sea of Japan and Sea of Okhotsk. Mar Mamm Sci 8:143-151

Amano M, Yoshioka M, Kuramochi T, Mori K (1998) Diurnal feeding activity of Dall's porpoise, Phocoenoides dalli. Mar Mamm Sci 14:130-135

Bigg MA, Fawcett 1 (1985) Two biases in diet determination of northern fur seals (Callorhinus ursinus). ln: Beddington JR, Beverton RJH, Lavigne DM (eds) Marine mammals and fisheries. George Allen and Unwin, London, p 284-291

Clarke A, Clarke MR, Holmes LJ, Waters TD (1985) Calorific values and elemental analysis of eleven species of oceanic squids (Mollusca: Cephalopoda). J Mar Biol Assoc UK 65: 983-986

Clarke MR (1986) A handbook for the identification of cephalopod beaks. Clarendon, Oxford

Crawford TW (1981) Vertebrate prey of Phocoenoides dalli, (Dall's porpoise), associated with the Japanese high seas salmon fishery in the North Pacific Ocean. MSc thesis, University of Washington, Seattle

Frost KJ, Lowry LF (1981) Trophic importance of some marine gadids in nor thern Alaska and their body-otolith size relationships. Fish Bull US 79:187-192

Gaskin DE (1982) The ecology of whales and dolphins. Heinemann, London

Härkönen T (1986) Guide to the otolith of the bony fishes of the northeast Atlantic. Danibu ApS, Hellerup

Houck WJ, Jefferson TA (1999) Dall's porpoise Phocoenoides dalli (True, 1885). In: Ridgway SH, Harrison R (eds) Handbook of marine mammals. 6. Academic Press, London, p 443-471

Kizevetter IV (1971) Chemistry and technology of Pacific fish. Dal'izdat, Vladivostok. (Translation by the lsrael Program for Scientific Translations, 1973. Available from US Department of Commerce, National Information Service, Springfield, VA)

Kubodera T (1982) Ecological studies of pelagic squids in the 
subarctic Pacific region. PhD thesis, Hokkaido University, Hakodate (in Japanese)

Kubodera T (1986) On the treatment of the squids for study of trophic relationships. Report on the development of ecosystem modeling in the northern North Pacific. Fisheries Agency Japan, Tokyo, p 244-263 (in Japanese)

Kubodera T, Furuhashi M (1987) A manual for identification of myctophid fishes and squids in the stomach contents. Report on the development of ecosystem modeling in the northern North Pacific, supplement. Fisheries Agency Japan, Tokyo, (in Japanese)

Kuramochi T, Kubodera T, Miyazaki N (1993) Squids eaten by Dall's porpoises, Phocoenoides dalli in the northwestern North Pacific and in the Bering Sea. ln: Okutani T, O'Dor RK, Kubodera T (eds) Recent advances in cephalopod fisheries biology. Tokai Univeraity Press, Tokyo, p 229-240

Maeda T (1974) Distribution and migration of walleye pollock, and ocean environment. In: Nishiwaki M (ed) Resource biology. Tokyo University Press, Tokyo, p 99-106 (in Japanese)

Mårtensson PE, Gotaas ARL, Nordøy ES, Blix AS (1996) Seasonal changes in energy density of prey of northeast Atlantic seals and whales. Mar Mamm Sci 12:635-640

Mizuno M, Miyake H (1996) Abundance and ecological research on the pelagic fishes; walleye pollock. Hokkaido Wakkanai Fisheries Experimental Station Reports in 1994 fiscal year. Hokkaido Wakkanai Fischeries Experimental Station, Wakkanai, p 117-129 (in Japanese)

Nagasawa K, Torisawa M (1991) Fishes and marine invertebrates of Hokkaido: biology and fisheries. Kitanihon Kaiyo Center, Sapporo (in Japanese)

Naito M, Murakami K, Kobayashi T, Nakayama N, Ogasawara J (1977) Distribution and migration of oceanic squids (Ommastrephes bartrami, Onychoteuthis borealijaponicus, Berryteuthis magister and Gonatopsis borealis) in the western subarctic Pacific region. Research Institute of North Pacific Fisheries, Faculty of Fisheries Hokkaido University Special Volume, p 321-337 (in Japanese with English abstract)

Nishimura S (1974) Establishment of the Sea of Japan. Tsukijishokan, Tokyo (in Japanese)

Noguchi E (1946) Dolphins and their utilization. In: Noguchi E, Nakamura R (eds) Utilization of dolphins and mackerel fishery. Kasumigasekishobou, Tokyo, p 3-36 (in Japanese)

Editorial responsibility: Otto Kinne (Editor),

Oldendorf/Luhe, Germany
Okiyama M (1993) Kinds, abundance and distribution of the oceanic squids in the Sea of Japan. In: Okutani T, O'Dor RK, Kubodera T (eds) Recent advances in cephalopod fisheries biology. Tokai University Press, Tokyo, p 403-415

Oya T, Shimada K, Toyoda Y (1937) On the fat-content of Engraulis japonicus T. \& S. Bull Jpn Soc Sci Fish 6:147-150 (in Japanese with English abstract)

Perez MA (1994) Calorimetry measurements of energy value of some Alaskan fishes and squids. NOAA Tech Mem NMFS-AFSC-32

Perez MA, Bigg MA (1986) Diet of the northern fur seals, Callorhinus ursinus, off western North America. Fish Bull 84: 957-971

Resources Council (1982) Standard tables of food composition Japan, 4th edn. Science and Technology Agency Japan, Tokyo, (in Japanese)

Sasaki M (1987) Result of tagging experiment in young Arabesque greenling Pleurogrammus azonus Jordan et Metz, in the southwest Okhotsk Sea. Mon Rep Hokkaido Fish Exp Stn 44:217-223 (in Japanese)

Sekiguchi K (1994) Studies on feeding habits and dietary analytical methods for smaller odontocete species along the Southern African coast. PhD thesis, University of Pretoria

Smale MJ, Watson G, Hecht T (1995) Otolith atIas of South African marine fishes. lchthyological monographs of the JLB Smith Institute of Ichthyology, No. 1. JLB Sinith Institute of lchthyology, Grahamstown

Tollit DJ, Greenstreet SPR, Thompson PM (1997) Prey selection by harbour seals, Phoca vitulina, in relation to variations in prey abundance. Can J Zool 75:1508-1518

Walker WA (1996) Summer feeding habits of Dall's porpoise, Phocoenoides dalli, in the southern Sea of Okhotsk. Mar Mamm Sci 12:167-181

Watanabe Y, Zenitani H, Kimura R (1995) Population decline of the Japanese sardine Sardinops melanostictus owing to recruitment failures. Can J Fish Aquat Sci 52:1609-1616

Wilke F, Nicholson AJ (1958) Food of porpoises in waters off Japan. J Mamm 39:441-443

Wilke F, Taniwaki T, Kuroda N (1953) Phocoenoides and Lagenorhynchus in Japan, with notes on hunting. J Mamm 34:488-497

Wolff GA (1984) Identification and estimation of size from the beaks of 18 species of cephalopods from the Pacific Ocean. NOAA Tech Rep NMFS-17

Submitted: August 26, 1999; Accepted: February 1, 2000

Proofs received from author(s): June 27, 2000 